\title{
Assessment of biofertilizer quality and health implications of anaerobic digestion effluent of cow dung and chicken droppings
}

\author{
M.I. Alfa ${ }^{\text {a,*, D.B. Adie }}{ }^{\text {a }}$, S.B. Igboro ${ }^{\text {a }}$, U.S. Oranusi ${ }^{\text {b }}$, S.O. Dahunsi ${ }^{\text {b }}$, D.M. Akali ${ }^{\text {a }}$ \\ ${ }^{a}$ Department of Water Resources \& Environmental Engineering, Ahmadu Bello University, Zaria, Nigeria \\ ${ }^{\mathrm{b}}$ Department of Biological Sciences, Covenant University, Ota, Nigeria
}

\section{A R T I C L E I N F O}

\section{Article history:}

Received 27 December 2012

Accepted 27 September 2013

Available online 5 November 2013

\section{Keywords:}

Biofertilizer

Digestate

Pathogen reduction

Retention time

Total solids

Treatment efficiency

\begin{abstract}
A B S T R A C T
Anaerobic digestate have been identified as a rich source of essential plant nutrients. Nevertheless, its safety measured by the concentration of pathogen present is of great concern to end users. This research explored the efficiency of the mesophilic biodigestion process in the stabilization and sanitization of cow dung and chicken droppings. Six (6) kg each of cow dung and chicken droppings were collected fresh and free from impurities, pre-fermented, mixed with water in the ratio $1: 1 \mathrm{w} / \mathrm{v}$ to form slurry, fed into the respective reactors and digested for 30 days at an average ambient temperature of $30 \pm 2{ }^{\circ} \mathrm{C}$. The pH of the medium fluctuated between 6.5 and 8.0. The analysis of the feedstock and effluent of the digesters showed that a total solids reduction of $75.3 \%$ and $60.1 \%$ were recorded for cow dung and chicken droppings while the reduction in total coliforms was $95 \%$ and $70 \%$ respectively for the dung and droppings. Microbial analysis of the biofertilizer produced reveals both aerobic and anaerobic organisms which include species of Pseudomonas, Klebsiella, Clostridium, Bacillus, Bacteroides, Salmonella, Penicillum and Aspergillus. Escherichia coli and Shigella spp. were removed while species of Salmonella and Klebsiella were still present in the digestate. Notwithstanding these results, the digestate still requires further treatment for it to be suitable for application on unrestricted crops either as fertilizer; otherwise a health problem would be created as attempt is made to improve soil fertility.
\end{abstract}

(ㄷ) 2013 Elsevier Ltd. All rights reserved.

\section{Introduction}

Anaerobic digestion is the controlled degradation of organic waste in the absence of oxygen and in the presence of anaerobic microorganisms [1]. The process generates a product called "biogas" that is primarily composed of methane, carbon dioxide, and compost products suitable as soil conditioners on farmlands [2]. Anaerobic digestion can be seen as a method to treat the organic wastes [3].

The need for adequate sanitation and energy especially in SubSaharan Africa where only $36 \%$ of the population is served with improved sanitation facilities, and only $58 \%$ are served with a safe and clean water supply [4] has made biogas technology a welcomed development. The development of biogas technology will facilitate the achievement of the Millennium Development Goals (MDGs) of the United Nations. The first goal of the MDGs is to eradicate extreme poverty and hunger. Thus, by utilizing the slurry (the

\footnotetext{
* Corresponding author. Tel.: +234 7030288424, +234 8053664892.

E-mail addresses: meshilalfa@gmail.com, meshachalpha@yahoo.com (M.I. Alfa).
}

digested waste) that is produced from the biogas systems, a community can fertilize its crops and also improve the composition of its soil [5]. There exist abundant evidence that climate change is a severe threat to socio-economic development and can substantially affect a nation's GDP, as it affects water, forest, sanitation, food security, industrial development, housing, energy, health and the very air we breathe [6]. Thus, development of biogas technology is a suitable alternative energy source that would be affordable and environmentally friendly that would help preserve the green forest thus achieving the 7th mandate of the Millennium Development Goal on environmental sustainability.

Biofertilizers are preparations containing living cells or latent cells of efficient strains of microorganisms that help crop plants' uptake of nutrients by their interactions in the rhizosphere when applied through seed or soil [7]. They accelerate certain microbial processes in the soil which augment the extent of availability of nutrients in a form easily assimilated by plants and also mobilizing nutritive elements from non- usable form to usable form through biological processes [8]. Anaerobic digestion draws up carbon, hydrogen and oxygen from the feedstock. Meanwhile, essential plant nutrients (nitrogen $(\mathrm{N})$, phosphorus $(\mathrm{P})$ and potassium $(\mathrm{K})$ ) 
remain largely in the digestate [9]. The availability of nutrients is higher in digestate than in untreated organic waste. For instance, digestate has $25 \%$ more accessible $\mathrm{NH}_{4}-\mathrm{N}$ (inorganic nitrogen) and a higher $\mathrm{pH}$ value than untreated liquid manure [3].

The quality and composition of the dewatered digestate solid depend on the feedstock and the digestion process [10]. More so, the dewatering separates the digestate into two fractions: the fibre and the liquid effluent. The fibre is bulky and contains a low level of plant nutrients thus can be used as a soil conditioner and as low grade fertilizer although further processing of the fibre such as through composting can produce good quality compost. Whereas, the liquid effluent on the other hand contains a large proportion of nutrients and can be used as a fertilizer. The high water content of the liquor facilitates its application through conventional irrigation methods. Thus, the use of fibre and liquor from anaerobic digestion has led to improved fertilizer utilization and therefore less chemical consumption in cropping systems [3].

Notwithstanding this huge benefit of the anaerobic digestate in the improvement of soil fertility and consequently crop production, the safety of the digestate, measured by the concentration of pathogens present, is of great concern to end users [10]. Pathogens like Salmonella spp., Escherichia coli, Shigella spp., Klebsiella spp., etc may contaminate the biogas slurry. Among them, some of the bacteria are hardy and do not get destroyed during the digestion period. Some pathogens survive better in the wet condition and these organisms may still be present in slurry even after digestion [11]. The availability of liquid biofertilizer in the market is on the increase as one of the alternatives to chemical fertilizer and pesticides, one of its benefits is in the population of microorganisms present [12]. Poor farm management techniques and improper use of agrochemicals has resulted in both soil quality and environmental degradation [13]. Therefore, the common objectives of biofertilizer is to provide socioeconomic and ecological benefits among which is soil quality improvement that contributes immensely to food quality and safety, human and animal health as well as environmental quality [14]. Most animal husbandry in Nigeria revolves predominantly around cattle and poultry among others. Thus these materials are more available in most commercial farms and would be more readily available used than other animal substrates for Biogas generation in Nigeria.

The objective of this study therefore is to assess the efficiency of the anaerobic digestion at mesophilic temperature range in the treatment of cow dung and chicken droppings in order to establish if the pathogen removal is sufficient to use the effluent as fertilizer.

\section{Materials and method}

\subsection{Materials}

Two 25 L-biogas digester tanks each of height $0.5 \mathrm{~m}$ and diameter $0.25 \mathrm{~m}$ were fabricated from Galvanized steel which is strong enough to withstand the weight and pressures of the contained slurry. The cylindrical shape was adopted to enhance better mixing. The tank is air tight and is clearly placed above the ground level and outside the shed where it is exposed to the sunlight for partial heating. pH meter model pHS-2S, (SHANGHAI JINYKE REX, CHINA) was used for measuring the $\mathrm{pH}$ of slurry every week day throughout the retention period, Gallenhamph Weight balance, Mettler P160N was used for measuring the weight of evaporating dish and sample for Total Solid analysis, UNISCOPE SM9053 oven was used to evaporate the sample for total solid analysis to dryness and UNISCOPE $2 / 1{ }^{\circ} \mathrm{C}$ thermometers was used to obtain daily temperature of the digester as well as the ambient temperatures of the environment.

\subsection{Method of fabrication of digesters, biomass collection, slurry preparation and digester loading}

The design volume of the two identical anaerobic digesters was sized according to the amount of volatile solids that must be treated daily and the period of time the material will remain in each of the digesters (Retention time). The design of the digesters was based on Ajoy Karki's Biogas model [15] incorporating the separate floating gas holder system for ease of measurement of gas volume. The cylindrical shape was adopted to enhance better mixing. The digester is a separate component, with the gas holder in a separate water jacket.

The theory behind the design is simply "downward delivery and upward displacement". The slurry on fermenting in the digester produces gas. This gas is delivered to the bottom of the water jacket via a pipe; the pipe extends above the surface of the water level (water seal) in the water jacket. The gas displaces the gas holder (upward) and gets trapped between the gas holder and the water seal. The displacement of the gas holder is dependent on the pressure and volume of the gas produced. The setup is as shown in Fig. 1.

Cow dung was collected fresh and free from impurities from the Zango abattoir in Zaria, Kaduna state, Nigeria while the chicken droppings were collected fresh and also free from impurities (such as wood shavings and iron filings) from the poultry department of the National Animal Production Research Institute (NAPRI), Shika, Zaria, Kaduna State, Nigeria. They were stuffed into sterile bags and transported to the research laboratory of the Department of Water Resources and Environmental Engineering, Ahmadu Bello University, Zaria where they were subjected to further pre-treatment. The digestion was a batch process. Six (6) $\mathrm{kg}$ each of cow dung and chicken droppings were respectively mixed with water in the ratio $1: 1 \mathrm{w} / \mathrm{v}$ to form slurry and treated in the two purpose-built $25-\mathrm{L}$ anaerobic digesters. Each digester system comprised a prefermentation tank, a digester, a gas collection system and a digestate collection tank. The pre-fermented feedstock waste was added to the feed tank together with recycled digestate taken from the collection tank. The slurry was allowed to occupy three quarter of

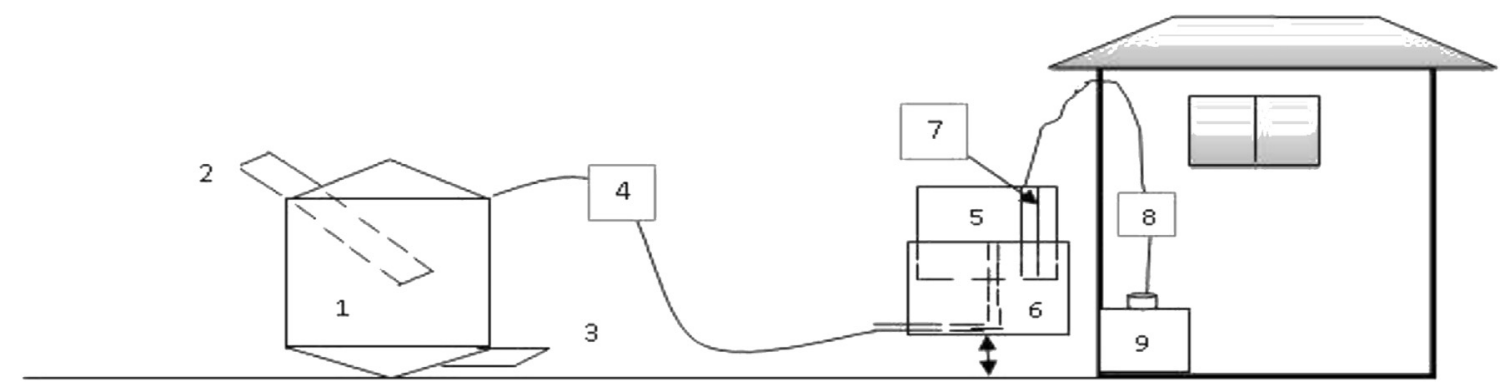

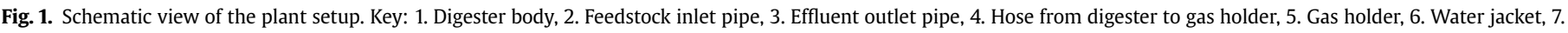
Rule, 8 . Hose to cooking stove, 9. Cooking stove in the kitchen. 
the digester space leaving a clear head space for the gas production. The inflow was directed downward to break scum as the new substrate drops and to cause the solids to accumulate at the bottom of the tank where after digestion they were easily removed. The slurry was digested for a 30 day retention period.

\subsection{Physico-chemical analysis and isolation of mesophilic microbe}

Samples of the feedstock and effluents of both digesters were taken for analysis of total solids content, $\mathrm{pH}$, total coliform count, total aerobic plate count, fungal count as well as biochemical characterization of microbial population in the biofertilizer. All the analyses were carried out based on standard methods [16-18].

Enumeration of microbial population of the biofertilizer was done by standard plate count using Nutrients agar, MacConkey agar, Eosin Methylene Blue agar and Fastidious Anaerobic agar plates for bacteria while Potato Dextrose agar (PDA) plus Chloramphenicol was used for fungi. Nutrient agar, MacConkey and EMB agar plates were incubated at $37^{\circ} \mathrm{C}$ for $24-48 \mathrm{~h}$, PDA plates were incubated at room temperature for 3-5 days while Fastidious Anaerobic agar plates incubated in an anaerobic jar (Oxoid) containing a moistened pack of gas generating kit (Bio-oxoid) at $37^{\circ} \mathrm{C}$ for 7 days. Individual colonies were purified and identified by morphological and biochemical techniques [19]. For fungal isolates, the microscopic and macroscopic features of the hyphal mass, morphology of cells and spores, nature of the fruiting bodies, among other criteria were used for identification [20].

The Biogas yield and the concentration of methane in the gas were also monitored daily. The methane content was estimated by comparing the volume of gas produced before and after removal of carbon dioxide via lime scrubbing.

In order to make compost with the digestate, the slurry was removed from the digester after the 30 day period of digestion, collected in sterile sacks, dewatered, allowed to cure for 20 days in the sterile sacks and stored until it was applied to the demonstration plots. Also noted at this stage was the $\mathrm{pH}$ of the slurry before and after conversion to biofertilizer.

A demonstration farm was acquired and partitioned into three plots. After mixing the cured compost for homogeneity, $1.7 \mathrm{~kg}$ of the compost was applied to each portion of the plot allocated for it before the planting and a month after germination and subsequently a month after the last application. Also, $1 \mathrm{~kg}$ of N.P.K 15:15:15 (inorganic fertilizer) was applied to the required portions of the plots with the first application on the fourteenth day after planting, and subsequently on the twenty eight and thirty six days after planting. While two identical plots was left to serve as control (without fertilizer application).

Two varieties of crops were planted separately on the farm they are maize and guinea corn with a space of $10 \mathrm{~cm}$ between each plant.

The day of germination was noted and subsequently the plant heights and the width of stems of the plant within each plot were measured at first, every three days after germination and later after every week until the plants started flowering.

The plant were harvested on maturity, weighed on the field and allowed to dry for three weeks. The weight of the dried produces was noted and the produces was shelled and weighed again.

Soil samples were taken from the farm first randomly for analysis before planting and secondly from two identical plots based on the kind of treatment the plot was subjected.

\section{Results}

The average ambient temperature during the period of study was $30 \pm 2{ }^{\circ} \mathrm{C}$ while the average digester temperature was $32.6 \pm 2{ }^{\circ} \mathrm{C}$. Fig. 2 shows a comparison of the total solids of the

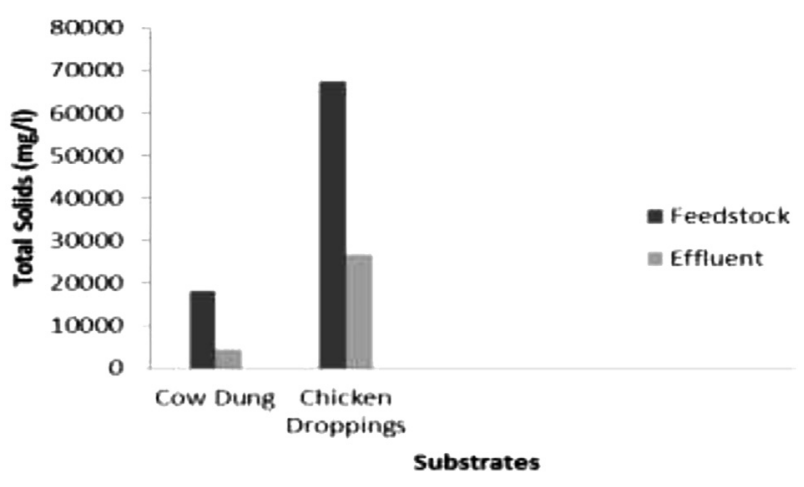

Fig. 2. Comparison of total solids of feedstock and effluent.

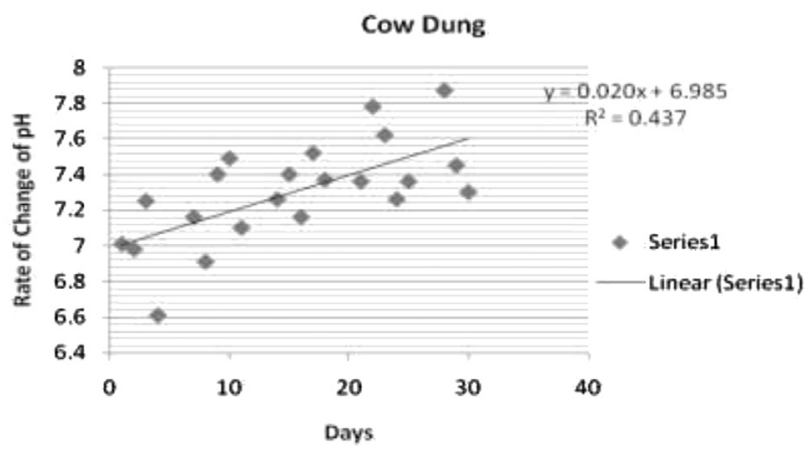

Fig. 3. Rate of change in $\mathrm{pH}$ of the cow dung at various time intervals

feedstock and effluent for both cow dung and chicken droppings. It reveals that the total solid in the feedstock reduced by over $50 \%$ as seen in the effluent.

The $\mathrm{pH}$ of the two digesters fluctuated optimally from between 6.6 and 7.8 for cow dung (Fig. 3) and from between 6.4 and 8.8 for chicken droppings (Fig. 4).

The daily biogas production of $6.35 \times 10^{-3} \mathrm{~m}^{3}(65.59 \%$ methane content) and $7.03 \times 10^{-3} \mathrm{~m}^{3}(61.71 \%$ methane content) were recorded over a 30-day retention period with a standard deviation of $2.89 \times 10^{-3}$ and $4.8^{-3}$ for cow dung and chicken droppings respectively.

Table 1 shows the microbial profile of feedstock and biofertilizer digestate. The mean microbial counts of the cow dung and chicken droppings feedstock respectively before digestion were $4.0 \times 10^{8}$ and $2.0 \times 10^{8}$ for coliform, $3.4 \times 10^{10}$ and $1.7 \times 10^{10}$ for total aerobic

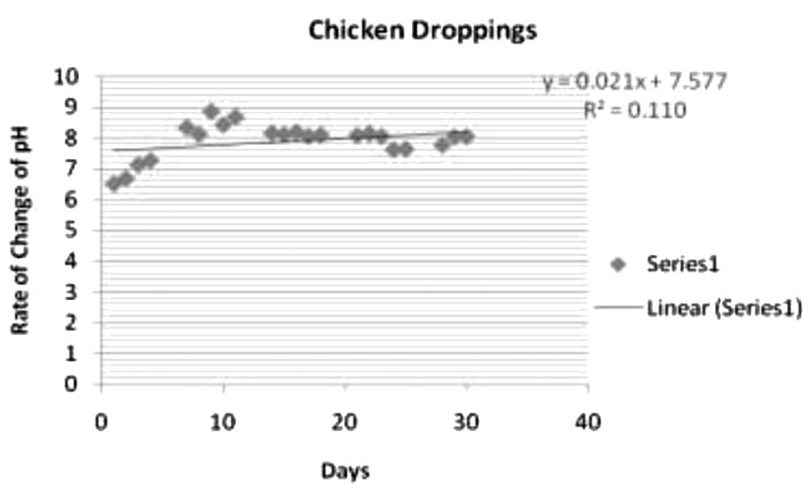

Fig. 4. Rate of change in $\mathrm{pH}$ of the chicken droppings at various time intervals 
Table 1

Microbial profile of feedstock and biofertilizer digestate.

\begin{tabular}{|c|c|c|c|c|c|c|c|}
\hline \multicolumn{3}{|c|}{ Total coliforms (CFU/100 ml) } & \multicolumn{2}{|c|}{ Total aerobic plate count } & \multicolumn{2}{|c|}{ Fungal count } & \multirow[t]{2}{*}{ Species of organisms isolated } \\
\hline Substrates & Cow dung & $\begin{array}{l}\text { Chicken } \\
\text { droppings }\end{array}$ & Cow dung & $\begin{array}{l}\text { Chicken } \\
\text { droppings }\end{array}$ & Cow dung & $\begin{array}{l}\text { Chicken } \\
\text { droppings }\end{array}$ & \\
\hline Feedstock & $4.0 \times 10^{8}$ & $2.0 \times 10^{8}$ & $3.4 \times 10^{10}$ & $1.7 \times 10^{10}$ & $3.2 \times 10^{6}$ & $1.6 \times 10^{6}$ & $\begin{array}{l}\text { Escherichia, Citrobacter, Bacillus, Pseudomonas, } \\
\text { Proteus, Klebsiella, Enterobacter, Staphylococcus, } \\
\text { Streptococcus, Clostridium, Bacteroides, Aspergillus, } \\
\text { Mucor, Rhizopus, Shigella, Salmonella, Penicillum }\end{array}$ \\
\hline Digestate & $2.0 \times 10^{7}$ & $6.0 \times 10^{7}$ & $3.3 \times 10^{6}$ & $1.6 \times 10^{6}$ & $6.7 \times 10^{4}$ & $3.3 \times 10^{4}$ & \\
\hline
\end{tabular}

plate count (TAPC) and $3.2 \times 10^{6}$ and $1.6 \times 10^{6}$ for fungal count. For the cow dung and chicken droppings digestates respectively, the counts were respectively $2.0 \times 10^{7}$ and $6.0 \times 10^{7}$ for coliform, $3.3 \times 10^{6}$ and $1.6 \times 10^{6}$ for total aerobic plate count (TAPC) and $6.7 \times 10^{4}$ and $3.3 \times 10^{4}$ for fungal count. The microbial population found in the feedstock includes spp. of Escherichia, Citrobacter, $\mathrm{Ba}$ cillus, Pseudomonas, Proteus, Klebsiella, Clostridium, Bacteroides, Enterobacter, Staphylococcus, Streptococcus, Aspergillus, Mucor, Rhizopus, Shigella, Salmonella and Penicillium while those isolated from the biofertilizer digestate includes spp. of Pseudomonas, Klebsiella, Clostridium, Bacillus, Bacteroides, Penicillium, Shigella, Salmonella and Aspergillus. These organisms were implicated via biochemical tests described previously $[19,20]$.

The composition of the compost prepared from the digestates is shown on Table 2. The result reveals that the constituents of the cured compost was Carbon (39.90\%), Nitrogen (2.36\%), Nitrate $(0.011 \%)$, Nitrite $(0.037 \%)$, Ash content $(46.00 \%)$, Moisture content (16.45\%), Sulphate $(0.097 \%)$ and Phosphate $(2.37 \%)$ while the Carbon/Nitrogen ratio and $\mathrm{pH}$ were 16.91:1.00 and 7 respectively. The compost which was a dark humus like substance (Plate 1) was subsequently used to grow crops.

Furthermore, the results in Table 3 indicated that the compost plot had most of its nutrients and $\mathrm{pH}$ improved as compared to the baseline and other treated and non treated plots which agrees with previous related Mahony and O'Flaherty et al. [21] who suggest that compost has the ability to improve soil properties.

In addition, the $\mathrm{pH}$ values of the compost observed before curing for 20 days were 6.8 and 7.4 for cow dung and chicken droppings respectively while both were adjusted to 7.0 (Neutral) after curing for 20 days. This is a good $\mathrm{pH}$ for plant nutrients uptake as reported by Hartmann et al. [22] and David et al. [23] This could possibly explain why Magem [24] sludge could not support plant growth as they were not allowed to cure, though observation on $\mathrm{pH}$ was not noted during the study.

\section{Discussion}

There was a drastic reduction over of $50 \%$ (approximately $75.3 \%$ and $60.1 \%$ for cow dung and chicken droppings respectively) in total

Table 2

Composition of compost (manure) used as biofertilizer

\begin{tabular}{ll}
\hline Constituent component of digestate used as fertilizer & Percentage (\%) \\
\hline Carbon & 39.90 \\
Nitrogen & 2.36 \\
Carbon/nitrogen ratio & $16.91: 1.00$ \\
Nitrate & 0.011 \\
Nitrite & 0.037 \\
Ash content & 46.00 \\
Moisture content & 16.45 \\
Sulphate & 0.097 \\
Phosphate & 2.37 \\
pH & 7 \\
\hline
\end{tabular}

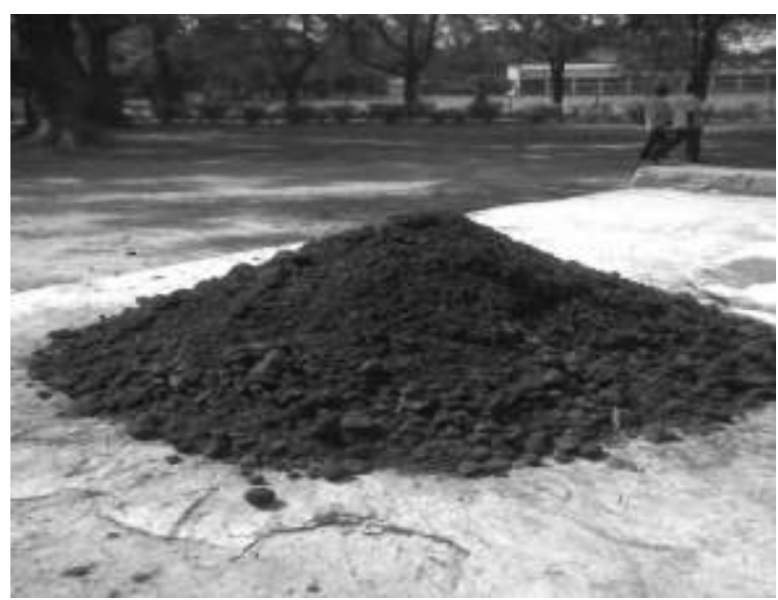

Plate 1. Cured compost prepared from digester slurry.

solid content of the feedstock. The ambient and digester temperatures of 30 to $35{ }^{\circ} \mathrm{C}$ and $\mathrm{pH}$ of $6-9$ recorded in this work could have contributed to enhanced activities of the organisms in digestion; it also confirms the conversion performance of the digester (treatment efficiency).

Species of bacteria and fungi isolated from the digestate biofertilizer includes Pseudomonas, Klebsiella, Clostridium, Bacillus, Bacteroides, Penicillum, Shigella, Salmonella and Aspergillus. Klebsiella and Clostridium spp. are known to be free-living nitrogen fixing biofertilizers and their presence in this preparation will boost its efficiency in nitrogen fixation when used for crops. Bacillus and Pseudomonas spp. are phosphate solubilizing biofertilizers, Bacillus species also act as solubilizers for trace elements like silicates and zinc as well as acting as plant growth promoters. Pseudomonas species are equally known to be excellent plant growth promoting rhizobacteria. Aspergillus and Penicillum species on their own are phosphate solubilizing fungi [8]. The presence of all these organisms makes the biofertilizer an excellent one. Inoculation of appropriate microbes to food wastes could shorten the period for maturity and improve the quality of biofertilizer [25-28]. Similarly, Yun et al. [29] and Crawford [30] reported that the metabolic heat generated by microorganisms during biofertilizer preparation

Table 3

Average soil condition of the field before and after cultivation.

\begin{tabular}{lllll}
\hline Samples & $\mathrm{pH}$ & $\begin{array}{l}\text { Total } \\
\text { nitrogen }(\%)\end{array}$ & $\begin{array}{l}\text { Available } \\
\text { phosphorous } \\
(\mathrm{ppm})\end{array}$ & $\begin{array}{l}\text { Potassium } \\
(\mathrm{cmo} / \mathrm{kg})\end{array}$ \\
\hline Baseline & 5.5 & 0.04 & 5.25 & 0.16 \\
Compost plot & 5.6 & 0.04 & 5.25 & 0.22 \\
NPK plot & 5.4 & 0.05 & 3.94 & 0.18 \\
$\begin{array}{l}\text { No treatment } \\
\quad \text { plot }\end{array}$ & 5.5 & 0.04 & 3.72 & 0.15 \\
\hline
\end{tabular}


destroys pathogen. The resulted biofertilizers are not only suitable for use as soil conditioners and fertilizers, but can also suppress soil-borne and foliar plant pathogens [27,31,32].

The mean microbial count revealed decreasing trend for coliform count, total aerobic plate count as well as fungal count in the biofertilizer digestate as against their higher values in the feedstock. This agrees with Shu-Hsien et al. [33] that microbial population has a tendency to decrease suddenly from day 1-7 due to the acidic environment and then remains steady during the biofertilizer preparation.

$\mathrm{pH}$ changes were closely related to degradation of food, vegetable and animal wastes during compost production [25,29,34,35]. Therefore, the observed change in pH (see Figs. 3 and 4) accounts for the reduced pathogen count in the biofertilizer as most pathogens cannot tolerate high $\mathrm{pH}$ levels.

Although the digestion process reduced the microbial load of the digestate marginally, the total coliform contents of $2.0 \times 10^{7} \mathrm{CFU} / 100 \mathrm{ml}$ and $6.0 \times 10^{7} \mathrm{CFU} / 100 \mathrm{ml}$ for cow dung and chicken droppings however were still above the tolerable limits for irrigation of unrestricted crops i.e crops that are consumed raw [36,37].

More so, the presence of Salmonella and Klebsiella spp. in the digestate calls for concern in its use on farm land. Salmonellae are known pathogens and could be transmitted to man and animals via contaminated food, feed and water [38]. Klebsiella spp. have been implicated in human infections [39] notwithstanding the earlier stated fact that it is a known nitrogen fixing bacteria whose presence will boost the efficiency of this biofertilizer [8]. The presence of Salmonella spp. in addition to the high levels of the total coliforms suggest that the digestate may not be safe for direct application as fertilizer for crops that are eaten raw thus further treatment is advised. This is not to discourage the use of digestate for improvement of soil fertility but that care should be taken to avoid disease transmission. Nevertheless, the reduction in total coliforms, total aerobic plate count and fungal count suggest that the anaerobic digestion process could remove pathogens of faecal origin if properly designed. Further studies to establish if an increase in retention time could further reduce the pathogens to tolerable limit is necessary.

The high yield of biogas from the feedstock, point to the fact that Cow dung and Chicken droppings are effective, cheap and readily available raw materials for green energy generation, further work on the generated gas is ongoing to determine their characteristic value.

Although this test was carried out adopting the batch digestion process, a further investigation into the semi-continuous digestion process is recommended. This would reduce the interval of acid formation and ensure a continuous supply of acids. More so, the source of the aforementioned substrates would probably be close to the anaerobic digestion plants in practice thus would make the operation of a semi-continuous process feasible.

\section{Conclusion}

The study has shown that the anaerobic digestion process could be an effective waste treatment option with respect to the reduction of total solids. Notwithstanding the marginal reduction of pathogens from both cow dung and chicken droppings after the anaerobic digestion, the concentration of total Coliforms only allows for restricted irrigation according to the WHO-guidelines for "safe use of waste water, excreta and greywater".

Further study could evaluate if an increase in the retention time would further reduce the pathogen content. The study therefore recommends that anaerobic digestate should be subjected to further treatment to reduce the pathogens to tolerable limits before applying to crops that are eaten directly. This attempt will solve soil fertility problem and not create an attendant health problem.

\section{References}

[1] Ojolo SJ, Dinrifo RR, Adesuyi KB. Comparative study of biogas production from five substrates. Adv Mater Res J 2007:18-19:519-25.

[2] Koberle E. Animal manure digestion systems in Central Europe. In: Proceedings of the second biomass conference of the Americas, August 21-24, vol. 23. Portland, Oregon: National Renewable Energy Laboratory (NREL); 1995. p. 34.

[3] Monnet F. An introduction to anaerobic digestion of organic waste, being a final report submitted to Remade. Scotland. Available from: http://www. remade.org.uk/media/9102/anintroductiontoanaerobicdigestionnov2003.pdf; 2003 [accessed May 2011].

[4] WHO. World health Organization and United Nations Children's Emergency Fund. Water for life: making it happen. France: Joint Monitoring Programme for Water Supply and Sanitation; 2005, ISBN 924156293 5; 2005. www.who. int/water_sanitation_health/waterforlife.pdf [accessed December 2008].

[5] UN. United Nations, the millennium development goals report 2006. New York, NY: Published by United Nations Department of Economic and Social Affairs; 2005.

[6] Machunga-Disu LL, Machunga-Disu Z. Sustainable management of natural resources and the need for revenue transparency, subsidy reform and full deregulation: the transformation from fossil fuel to green energy, green deal Nigeria. Nigeria: A Publication of Heinrich Boll Stiftung; 2012. Available from: http://ng.boell.org/downloads/Chapter_-_6_Oil_and_Gas_Technical_ Background Paper.pdf [accessed 17.05.12]

[7] Mishra BK, Dadlich SK. Methodology of nitrogen biofertilizer production. J Adv Developm Res 2010;1(1):3-6.

[8] Tamil Nadu Agricultural University (TNAU). Entrepreneurial training manual. Coimbatore: Tamil Nadu Agricultural University; 2008.

[9] Igboro SB. Production of biogas and compost from cow dung in Zaria, Nigeria. an Unpublished PhD Dissertation in the Department of Water Resources and Environmental Engineering. Zaria Nigeria: Ahmadu Bello University; 2011.

[10] Mata-Alvarez J, Mace S, Llabres P. Anaerobic digestion of organic solid wastes. An overview of research achievements and perspectives. Bioresour Technol 2003:74(1):3-16.

[11] Karki AB, Shrestha NJ, Bajgain S. Biogas as renewable energy source in Nepal: theory and development. Nepal: BSP; 2005. Available from: www.snvworld. org.

[12] Hasarin N, Viyada K. The study of shelf life for liquid biofertilizer from vegetable waste. Au J Technol 2008;11(4):204-8.

[13] Setboonsarng S, Gilman J. Alternative agriculture in Thailand and Japan [Internet] Available from: http://www.solutions-site.org/artman/publish/ article_15.shtml; 1999 [accessed March 2006].

[14] Parr JF, Hornick SB, Papendick RI. Transition from conventional agriculture to natural farming systems: the role of microbial innoculants and biofertilizer [Internet] Available from: http://www.emtech.org/data/pdf/0103.pdf; 2002 [accessed March 2006]

[15] Karki A. From kitchen waste to biogas: an empirical experience. In: Biogas and natural resources management 2002. No. 75.

[16] APHA. Standard method for the examination of water and wastewater. 19th ed. Washigton D.C.: American Public Health Association Inc; 1995.

[17] Gomis SM, Riddell C, Potter AA, Allan BJ. Phenotypic and genotypic characterization of virulence factors of Escherichia coli isolated from broiler chickens with simultaneous occurrence of cellulitis and other colibacillosis lesions. Can J Vet Res 2001;65:1-6.

[18] Bopp CA, Brenner FW, Wells JG, Strockbine NA. Escherichia, Shigella and Salmonella. In: Murray PR, Baron EJ, Pfaller MA, Tenover FC, Yolken RH, editors. Manual of clinical microbiology. Washington, DC: American Society for Microbiology; 2005. p. 459-74.

[19] Jolt JG, Krleg NR, Sneath PHA, Stanley JT, Williams ST. Bergey's manual of systematic bacteriology. 9th ed. Baltimore, Maryland: William and Wilkins CO.; 1994 P786.

[20] Tsuneo. Pictorial atlas of soil for seed fungi: morphologies of cultural fungi for key to species. 3rd ed. CRC Press; 2010.

[21] Mahony T, O'Flaherty V. Feasibility study for centralised anaerobic digestion for the treatment of various wastes and wastewaters in sensitive catchment Areas. Ireland: Environmental Protection Agency; 2002.

[22] Hartmann HT, Dale EK, Davies Jr FT, Geneve Rl. Plant propagation, principles and practices. 6th ed. New Dehli: Prentice Hall of India Private Limited; 2002. p. 770.

[23] David W, Adrian C, Carl W. Garden notes. Colorado State University; 2008. www.cmg.colostate.edu [accessed September 2010].

[24] Magem E. Biogas production from agriculture residues and fertilizer potentials of digester sludge. Unpublished M.Sc thesis. Department of Biological Sciences Ahmadu Bello University; 1995.

[25] Chen KS, Lin YS, Yang SS. Isolation and application of thermo-tolerant microbes in composting. I Agric Assoc China New Ser 1998;183:97-112.

[26] Chin HS, Huang CC, Chen KS, Yang SS. Cellulase activity of thermophilic actinimycetes and their effects on the quality of rice straw compost. J Agric Assoc China New Ser 1999;185:58-71. 
[27] Yang SS. Recent advance in composting. In: Huang SF, Pan SY, Kao CF, editors. Proceedings of the international seminar on issues in the management of agricultural resources. September 6-8, 2000. Food and Fertilizer Technology Centre for the Asian and Pacific Region (FFTC). Taipei, Taiwan: National Taiwan University; 2000. p. 166-85.

[28] Yang SS, Chen KS. Application of thermophilic microbes for preparing biofertilizers. Plant Prot Bull Spec Publ New 2003;5:267-91.

[29] Yun YS, Park JI, Suh MS, Park JM. Treatment of food wastes using slurry-phase decomposition. Bioresour Technol 2000:73:21-7.

[30] Crawford JH. Composting of agricultural wastes: a review. Proc Biochem $1983 ; 2: 14-8$.

[31] Hadar Y, Mandelbaum R. Suppressive compost for bio control pfsoil-borne plant pathogens. Phytoparas 1992;20:113-6.

[32] Zang W, Han DY, Dick WA, Davis KR, Hoitink HAJ. Compost and compost water extract-induced systemic acquired resistance in cucumber and Arabidopsis. Phytopathology 1998;88:450-5.

[33] Shu-Hsien T, Ching-Piao L, Shang-Shyng Y. Microbial conversion of food wastes for biofertilizer production with thermophiliclipolytic microbes. Renew Ener 2007;32:904-15.
[34] Yang SS, Chang SC, Wei CB. Properties of livestock and poultry wastes during composting. J Biomass Energy Soc China 2003;19:49-61.

[35] Pai CR, Wu CF, Sun RY, Wei CB, Yang SS. Composition analysis of livestock and poultry wastes during composting. J Biomass Energy Soc China 2003;22: 57-71.

[36] WHO. World Health Organization health guidelines for the use of wastewate in agriculture and aquacultureIn Technical report series no 778. Geneva: World Health Organization; 1989. Available from: http://whqlibdoc.who.int/ trs/WHO TRS 778.pdf.

[37] WHO. World Health Organization health guidelines for the use of wastewater in agriculture. Geneva: World Health Organization; 2004. Available from: http://www.who.int/water_sanitation_health/index.html.

[38] Eni AO, Ibukunoluwa AO, Oranusi US. Microbial quality of fruits and vegetables sold in Sango Ota, Nigeria. Afr J Food Sci 2010;4(5):291-6.

[39] Cuzon G, Naas T, Guibert M, Nordmann P. In vivo selection of imipenemresistant Klebsiella pneumoniae producing extended-spectrum beta-lactamase CTX-M-15 and plasmid-encoded DHA-1 cephalosporinase. Int J Antimicrib Agents 2010;35(3):265-8. 